\title{
The Change Laboratory in Higher Education: research- intervention using activity theory
}

\author{
Brett Bligh \& Michelle Flood
}

\begin{abstract}
In this chapter we discuss the Change Laboratory as an intervention-research methodology in higher education. We trace its theoretical origins in dialectical-materialism and activity theory, consider the recommendations made by its main proponents, and discuss its use in a range of higher education settings. We suggest that the Change Laboratory offers considerable potential for higher education research, though tensions between Change Laboratory design recommendations and typical higher education contexts require consideration.
\end{abstract}

\section{Introduction}

The Change Laboratory is an intervention-research methodology where people work together in a structured and cyclical way to envisage new activity in their organisation (Engeström, Rantavuori \& Kerosuo, 2013; Virkkunen \& Newnham, 2013). Local participants work with researcherinterventionists in an activity whose object is to produce other activities. The methodology prioritises challenging conventional wisdom and reconceptualising activity. Used in technology companies, heavy industry, hospitals and schools, Change Laboratory examples in higher education research are embryonic but promising. We argue that the Change Laboratory is a widely applicable intervention-research methodology — it could and should be applied to far more varied research objects in higher education research than has been the case hitherto.

The Change Laboratory is closely-coupled to activity theory. Understanding the theory-method relations is crucial, and matches well the aims of the present volume. The Change Laboratory is a direct attempt to foster expansive learning, a concept developed by Engeström (1987/2015), in which people work together to re-imagine the object of their activity. In turn, expansive learning is explicitly an example of what Karl Marx called ascending from the abstract to the concrete (Engeström, 1987/2015). Ascending from the abstract to the concrete means a cyclical process intertwining conceptual and empirical development, based on the qualitative movement of categories (Horn, 2013). Change Laboratory participants develop concepts in an organisational pilot-unit and aim for their step-wise implementation in the organisation.

Organisational change is an important topic in higher education research and there are similarities between prominent conceptions in the literature and the Change Laboratory. For example, Fullan's (1999) framework of "change lessons" involves viewing organisations as living systems that make breakthroughs by managing conflict and diversity (pp. 14-16). The Change Laboratory, correspondingly, is underpinned by a variant of activity theory that studies activity systems developing as a result of people overcoming systemic contradictions. Fullan emphasises the need for both top-down and bottom-up initiative within organisations, while the Change Laboratory aims to foster an oscillation between moments of each within the same intervention. Yet the extent of the 
similarity is limited. Fullan's notion of conflict emphasises the personal while the Change Laboratory focusses on problems in local practice taken as indicative of wider systemic incongruity. Moreover, higher education research frequently emphasises sector-wide discourse-for example, around "new managerialism" (Tight, 2012, p. 134)—whereas the Change Laboratory focusses on how institutional forms actually unfold locally.

It is important to emphasise that the Change Laboratory has potential for wider applicability in the field than organisational change. Consider Tight's (2012) overview of pertinent higher education research topics. Change Laboratory research-interventions might help imagine future possibilities for course, curricula and system policy design; develop concepts for researching student experience and academic work; undertake historical-analysis into the changing mission of institutions; and develop the transformative agency of marginalised voices in higher education. In doing so, the Change Laboratory would focus on developmental intervention. Understanding the Change Laboratory as a distinct form of interventionism is, therefore, important for understanding its potential.

By comparison to other interventionist methodologies popular in educational research, the Change Laboratory is relatively prescriptive. Engeström, Sannino \& Virkkunen (2014) emphasise that the Change Laboratory "follows specific methodological steps, which are flexible, but not situationally improvised" (p. 123). The reasons for this are theoretically-driven. There are several methodological fault-lines.

The Change Laboratory and action research view process models and discourse differently. Action research practitioner Darwin (2011) suggests that the expansive learning model is hegemonic within the Change Laboratory and so interventions are pre-ordained. Conversely, the developers of the Change Laboratory are concerned that models underpinning action research are too general; discussing the attendant use of Lewin's (1947) unfreezing-moving-freezing sequence, Engeström (2008) comments that "[w]hen a model is too general and unspecific, it is practically impossible to test it and develop it critically; almost any process will fit it" (p. 131). Darwin suggests that discourse within the Change Laboratory has an atmosphere of "experimentation that is argumentative, provocative and actively guided" (p. 218). Where action research foregrounds person-person discourse, the Change Laboratory focusses on how action is mediated by particular artefacts.

The Change Laboratory and design-based research apply theories at different levels within interventions (Penuel, 2014). In the Change Laboratory, activity theory and expansive learning guide the design of the intervention; those concepts that participants develop are understood as valuable for innovation of local activity systems by practitioners. Design-based research, by contrast, involves design-experiments in real settings that-underpinned by pragmatist philosophy —aim to test the truth-value of a particular theory by embedding conjectures within a task design. The low-level task design and conjectures are therefore specified relatively rigidly. Conversely, the form taken by the design-experiment itself is relatively contingent; design-based research is eclectic and its practitioners are bricoleurs (ibid., p. 99). Engeström, Sannino \& Virkkunen (2014) suggest, additionally, that design-based research under-theorises the mediating role of artefacts and how 
innovation spreads through institutions, and relies on notions of agency that are constrained by their individualism.

Within the Change Laboratory, the action of analysis means examining historical developments and actual examples. Analogously, in this chapter we trace the development of the theoretical underpinnings, relate these to the design of the Change Laboratory methodology, and examine actual examples within higher education.

\section{Theory}

\section{Origin of the underlying theory}

The concept of activity developed within Enlightenment debates on the origin of human reason. At issue was whether rationality and sensory experience —of the "external"—could have the same ontological origin. Thinkers like Hegel positioned "activity" as a relation between subjective and objective realms, in response to dualists-like Kant—who argued that those realms were irreconcilably separate (Blunden, 2010). Karl Marx subsequently argued that human consciousness arises within activity under particular material conditions. Marx's work is the origin of many core positions of activity theory. Three Marxist positions will be directly consequential for our argument: dialectical-materialism, ascending from the abstract to the concrete, and the importance of change.

Marx's dialectical-materialist position is that the material world exists prior to human consciousness of it (materialism), and that increasing our knowledge of the world means understanding how apparently disparate phenomena are, in fact, deeply connected and constantly developing (dialectics). For Marx, human beings undertake to act because of those problems and circumstances that materially confront them. In doing so they make use of cultural artefacts, including at moments of creativity or change:

Men make their own history, but they do not make it just as they please; they do not make it under circumstances chosen by themselves, but under circumstances directly encountered, given and transmitted from the past. The tradition of all the dead generations weighs like a nightmare on the brain of the living. And just when they seem engaged in revolutionising themselves and things, in creating something that has never yet existed, precisely in such periods of revolutionary crisis they anxiously conjure up the spirits of the past to their service and borrow from them names, battle-cries and costumes in order to present the new scene of world history in this time-honoured disguise and this borrowed language (Marx, 1852/1979, pp. 103-104).

The term ascending from the abstract to the concrete implies intertwined processes of analysis and synthesis. The principle is that people confront the concrete world of living, interrelated complexity, produce abstract concepts that attempt to explain that complexity - in an impoverished form - and then re-examine the world through those concepts to produce a thought-concrete, thereby further developing their conceptual understanding.

Marx's work advocates a strong mutual dependence between theorisation and empirical support (Ollman, 2003; Blunden, 2010). Marx prioritised what he called "practical-critical" activity over 
introspection or narrow empiricism, and intervention over interpretation:

All mysteries which lead theory to mysticism find their rational solution in human practice and in the comprehension of this practice [...] The philosophers have only interpreted the world in various ways; the point is to change it (Marx, 1845/1976, p. 5, emphasis in original).

Activity theory was first developed in the early Soviet Union by people-like Vygotsky—using Marxist principles as a basis for a dialectical-materialist psychology.

\section{Vygotsky's approach to psychology}

Lev Vygotsky elaborated a theory of the development of human consciousness, or higher mental functions. To do so, Vygotsky examined mediated action within laboratory work, using particular experimental designs oriented towards development (i.e., change). We focus here on four pertinent Vygotskyan principles: consciousness-activity relations, mediation, the zone of proximal development and developmental research.

Building on Marx's notion of the origin of consciousness, Vygotsky suggested that higher mental functions - those not observable within other animals-are:

1. Socially determined;

2. Related to social relations through processes of internalisation and externalisation (Kaptelinin \& Nardi, 2006).

Vygotsky's position was that consciousness develops through the internalisation of relations that previously existed in the social world. Such internalisation involves "a redistribution of internal and external components within a function as a whole [which may generate] increased reliance on internal components at the expense of external ones" (Kaptelinin \& Nardi, 2006, p. 43, emphasis in original). Vygotsky suggested that internalisation operates on two separate, but related, dimensions: from external to internal, and from interpsychological (relations between people) to intrapsychological (relations operating as a function of the individual) (ibid., p. 47).

The term mediation implies that something is not immediate. At a minimum, then, if two objects are in a mediated relationship then something must be in-between them. Additionally, in the social sciences the term nearly always implies:

1. The conciliation of opposites ("poles");

2. The notion that those poles operate within a totality;

3. The active alteration of the poles themselves because of their mutual mediation (Williams, 1983).

Wertsch (2007) argues that Vygotsky uses the term mediation in at least two distinct ways (p. 178). Firstly, Vygotsky suggests that mediation underpins human action, by which is meant that humans act on the social and material world in ways mediated by artefacts, including physical and psychological tools (such as semiotic signs). Secondly-and related to the consciousness-activity relationship-mediation links social-historical processes with mental processes. This is because humans internalise those forms of mediation that have been developed in the cultural, social, 
institutional world around them.

In experimental studies, "Vygotsky's basic procedure was to encourage subjects to use a set of artificial stimuli, or signs that are overtly introduced into a subject's activity by an experimenter" (p. 181). The first-stimulus in dual-stimulation experiment is a task specification, while the secondstimulus is an external artefact introduced by the experimenter. Together, the artefact and experimenter represent the wider culture within the experiment. When the first-stimulus is introduced, the experimental subject focusses on the task. Yet when the second-stimulus is introduced the experimental subject does not focus on the artefact itself, but on using the artefact to mediate the task. Yet dual-stimulation attempts to accomplish more than mediation. The firststimulus task has been designed so that it cannot be addressed by the experimental subject acting alone; it requires them to "break out of a conflicting situation and change their circumstances" (Sannino, 2011, p. 584). Dual-stimulation aims to enable subjects to transform an apparently solution-less situation in which they have conflicted motives, thereby taking control of their subsequent action. If a subject does not partly internalise the tool, resolve their motive conflicts and increase their volition, then dual-stimulation has not been successful.

Vygotsky studied developmental change and called his approach developmental research. He investigated the zone of proximal development, the distance between independent problem-solving capability and that demonstrated in situations, such as dual-stimulation, where support is provided (Kaptelinin \& Nardi, 2006, pp. 48-49). The Change Laboratory seeks to apply a Vygotskyan, developmental approach in real-world, collective, organisational settings.

\section{Understanding collective activity}

For present purposes, we now turn to focus on the work of Aleksei Leontiev, who distinguished activity from action, and Yrjö Engeström, who introduced the activity system concept and Change Laboratory methodology. Engeström's work, which he calls cultural-historical activity theory (often abbreviated to CHAT), underpins most uses of activity theory within anglophone educational research. This variant of activity theory underpins the Change Laboratory and its concepts are directly used in attendant research-interventions.

Leontiev's studies of human collective activity suggested that human life differs from that of other animals in at least two crucial ways: firstly, humans' objects and needs are not natural, but are themselves the products of human activity; secondly, humans can separate life motives, objects of collective activity, and goals pursued by individual actions. Those latter distinctions are interrelated, but in problematic ways. Blunden (2010) summarises Leontiev's position thus:

The motive of an activity (such as production of cloth) is not translated directly into individuals' goals (which may be earning a wage). The problem of forming individuals' goals so that the individuals' actions are rearticulated to constitute activities which meet social needs is a problem of the social organization of labor. The goal of the individual's action arises only thanks to the representation of the activity in and through the mediation of social relations (p. 178).

For Leontiev, this social organisation of labour implies a distinction between the sense of an activity 
— from the vantage point of an individual participant — and the meaning of that activity from an external, societal perspective. It also implies the need for the division of labour, a term derived from political-economy (where, among others, it was used by Marx). People work together to meet social needs, but in different roles differentiated by speciality (areas of expertise) and authority (within some hierarchy).

Leontiev subsequently developed a formal distinction between three concepts-activity, action and operation-which are seen as related hierarchically. For Leontiev, activity refers to collective and sustained effort, regulated by an object of activity, and having both sense and meaning. Action refers to something more time-bounded and granular, regulated by a particular goal, which may be undertaken by an individual (though in a conscious, premeditated way). Operation refers to those routine processes that are used to adjust actions, regulated by current conditions (Kaptelinin \& Nardi, 2006, pp. 62-63). The fact that Leontiev used the term activity theory reflects the primary role he ascribed to the activity-level within the hierarchy: Leontiev suggested that activity generates actions, and that actions derive their meaning from their place within activity. Leontiev's work was grounded in Vygotskyan, developmental thought: through mediated processes of internalisation and externalisation, activities become actions, objects of previous activities become mediating artefacts, and so on.

This understanding of the dynamic, developmental relationships between activity, actions, operations, objects and goals continues to form the basis of the CHAT tradition of activity theory. Yet CHAT and the Change Laboratory also rely on how Engeström extended Leontiev's concept of activity.

Like Leontiev, Engeström's work highlights that artefact-mediation is important but not sufficient on its own for understanding human activity. Drawing on biological and environmental research, Engeström (1987/2015, pp. 59-62) considers how structural components of prior animal activity underwent transitions in the emergence of human activity. Initially, aspects of animal activitybased around individual survival, collective survival and social life-were ruptured by tool-making, division of labour and ritualistic traditions, each of which came to occupy a mediating role in separate, tripartite mediated relationships. At the point of breakthrough into cultural evolution, these separate relationships of ecological rupture became unified within political-economic life. Engeström (1987/2015, pp. 62-64) subsequently examines the requirements—set out by Marx in the Grundrisse manuscripts - to take into account interrelated processes of production, distribution, exchange and consumption when examining activity from a political-economic vantage point. For Engeström, the mediated triangle subject $\rightarrow$ artefact $\rightarrow$ object, which forms the basis of Vygotsky's model of action, represents merely the directly productive aspects of activity and overlooks other aspects that are socially-mediated. In addition to artefact-mediation, Engeström suggests (pp. 62-64) that the activity level within activity theory must also encompass:

- distribution: the division of objects, artefacts and people according to social regulations (as a mediated triangle community $\rightarrow$ division of labour $\rightarrow$ object);

- exchange: the further division of objects, artefacts, communication and interaction according to individual need (subject $\rightarrow$ rules $\rightarrow$ community); 
- consumption: the use of a product to satisfy a human need (community $\rightarrow$ subject $\rightarrow$ object).

Engeström's triangular model of the activity system represents the interlocking set of production, distribution, exchange and consumption in activity. Fig. 1 depicts a graphical summary of the model, including definitions of the various system elements, that we have previously used within Change Laboratory research-interventions. The fact that the activity system model is comprised of tripartite sub-triangles reflects the origin of human activity within ruptured animal activity, while the fact that the sub-triangles are interlocking represents how they have subsequently become distinctions within the unity of human activity. Importantly, the activity system is an explication of a unit of analysis for the activity-level within Leontiev's activity-action-operation hierarchy, notwithstanding that action and operation are not represented graphically:

The triangle of learning activity [...] should now be depicted as a three-level hierarchy. Each corner of the triangle would thus have three qualitatively different levels: that of overall activity, that of actions, and that of operations (Engeström, 1987/2015, p. 122).

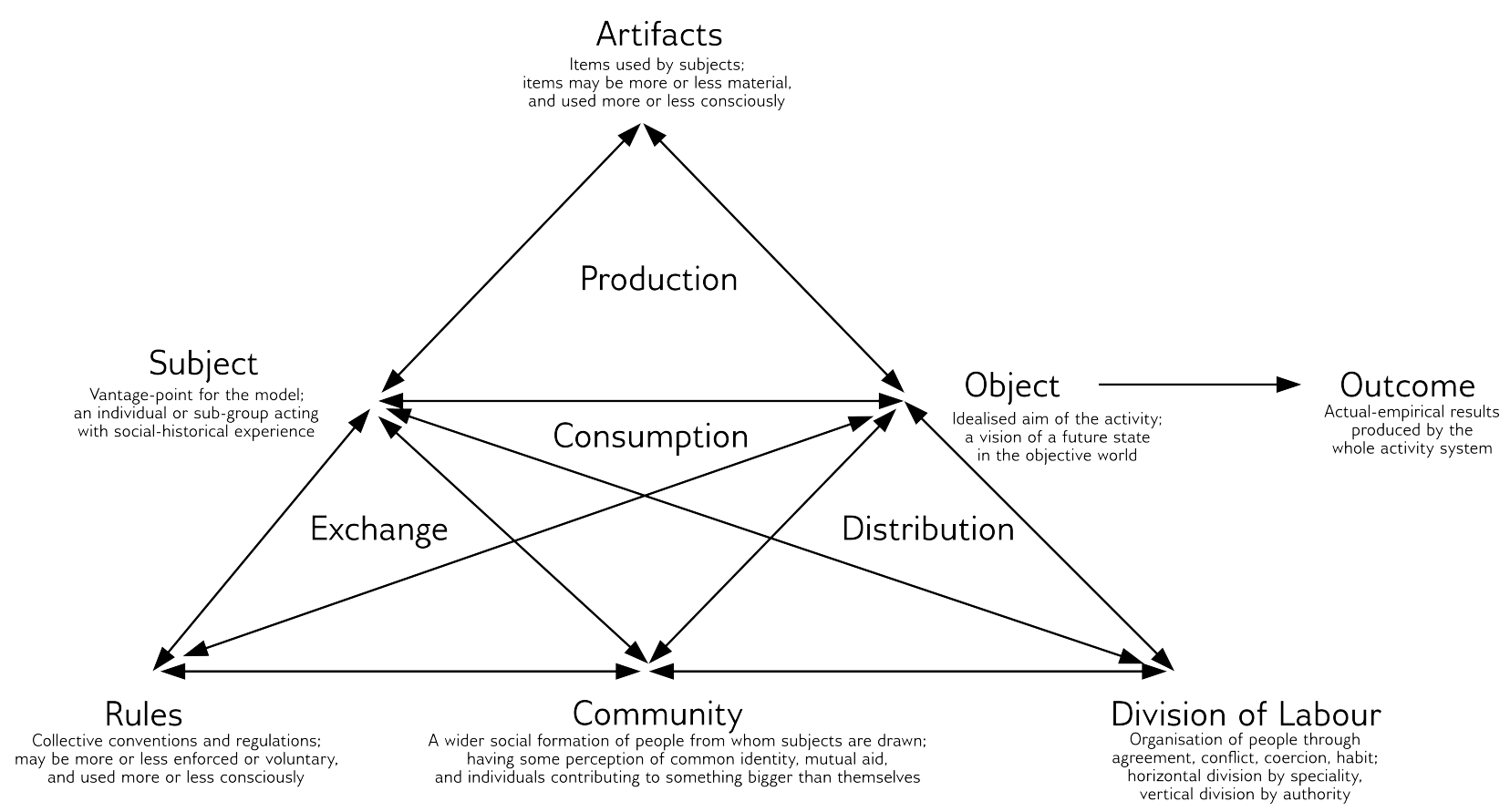

Figure 1: A graphical summary of the activity system model.

It is also crucially important that the model is grasped as an interrelated, dynamic system, rather than a list of elements. It is a matter of regret that:

sometimes it is used as a static classification structure to depict the elements of an activity system without analyzing the relationships of interaction between them and the possible contradictions within the system or making thought experiments to explore its developmental possibilities (Virkkunen \& Newnham, 2013, p. 44).

Engeström—like Marx and Vygotsky—foregrounds issues of development and change. Engeström suggests that systemic contradictions drive change, because people experience those contradictions as a variety of disturbances: as dilemmas, conflicts, inner doubts or double-binds (Virkkunen \& 
Newnham, 2013, p. 227). People strive to overcome those disturbances, and in doing so they change their activity systems. The Change Laboratory aims to render this process more directly visible to its participants.

Engeström developed the activity system model as part of his attempts to understand activity change of a special kind. This change-expansive learning —involves explicitly re-imagining activity itself, and by doing so expanding the object of activity. The Change Laboratory is a deliberate, direct attempt to foster expansive learning.

\section{Expansive learning and systemic contradictions}

The Change Laboratory applies principles analogous to Vygotsky's developmental researchincluding dual-stimulation task designs - in organisational settings. The developmental work research (typically abbreviated to DWR) methodology was developed in the mid-1980s, focussed on training and professional development, and the Change Laboratory was subsequently developed by the mid-1990s as an attempt to overcome contradictions in DWR (Virkkunen \& Newnham, 2013, p. 22). There is inconsistency in the literature as to whether the term "Change Laboratory" refers to those sessions used within a wider DWR methodology, or whether the Change Laboratory is a new methodology based on DWR. In this chapter we use the term Change Laboratory in the latter, enlarged sense, to refer to entire intervention-research projects. Yet some literature we draw on uses the former convention.

Considerable continuity of principle exists between early-DWR and the Change Laboratory. Virkkunen \& Newnham (2013) set out five dialectical relations embedded within DWR that Change Laboratory interventions strive to realise (pp. 24ff.). These relations emphasise back-and-forth movement between moments of: considering daily reality and distanced analysis; foregrounding practical improvement and generating new ideas; thinking about cyclical possibilities for change in short, medium and long terms; generating tools to design activities and tools to mediate those activities; and developing concepts and embedding those concepts in resources for practitioners' use.

To understand how the Change Laboratory works in practice, it is necessary to consider Engeström's models of systemic contradictions and expansive learning.

Contradiction is a longstanding principle of dialectics. The term refers to the incompatible development of different aspects of the same relation-poles_-where those aspects are mutually dependent. Poles might serve to block, undermine, or interfere with others, or their mutual transformation might occur. Ollman (2003) suggests that understanding contradiction is important for understanding historical development dialectically:

The future finds its way into this focus as the likely and possible outcomes of the interaction of these opposing tendencies in the present, as their real potential (p. 17).

Typically, contradictions are seen as arising from developing internal relations within a dialectical system (Ollman, 2003). Yet, within the context of activity theory, Engeström (1987/2015) highlights how internal contradictions "find their outward expressions in external ones" (p. 70). Specifically, 
Engeström suggests (pp. 69-73) that activity system contradictions (Fig. 1) can be distinguished thus:

- primary contradictions, within elements of the activity (often value-system conflicts; within capitalism, the contradiction is typically between a pole of use-value for practitioners and one of exchange-value in some market);

- secondary contradictions, between elements of the activity system;

- tertiary contradictions, between the existing forms of the activity system and attempts to apply a new model;

- quaternary contradictions, between an activity system and those that neighbour it.

Fig. 2 shows our representation of these different forms of systemic contradiction-including the relatively common scenario where value-system conflicts in the object result from its contestation by different activity systems - in a form that we have found useful for Change Laboratory researchinterventions.

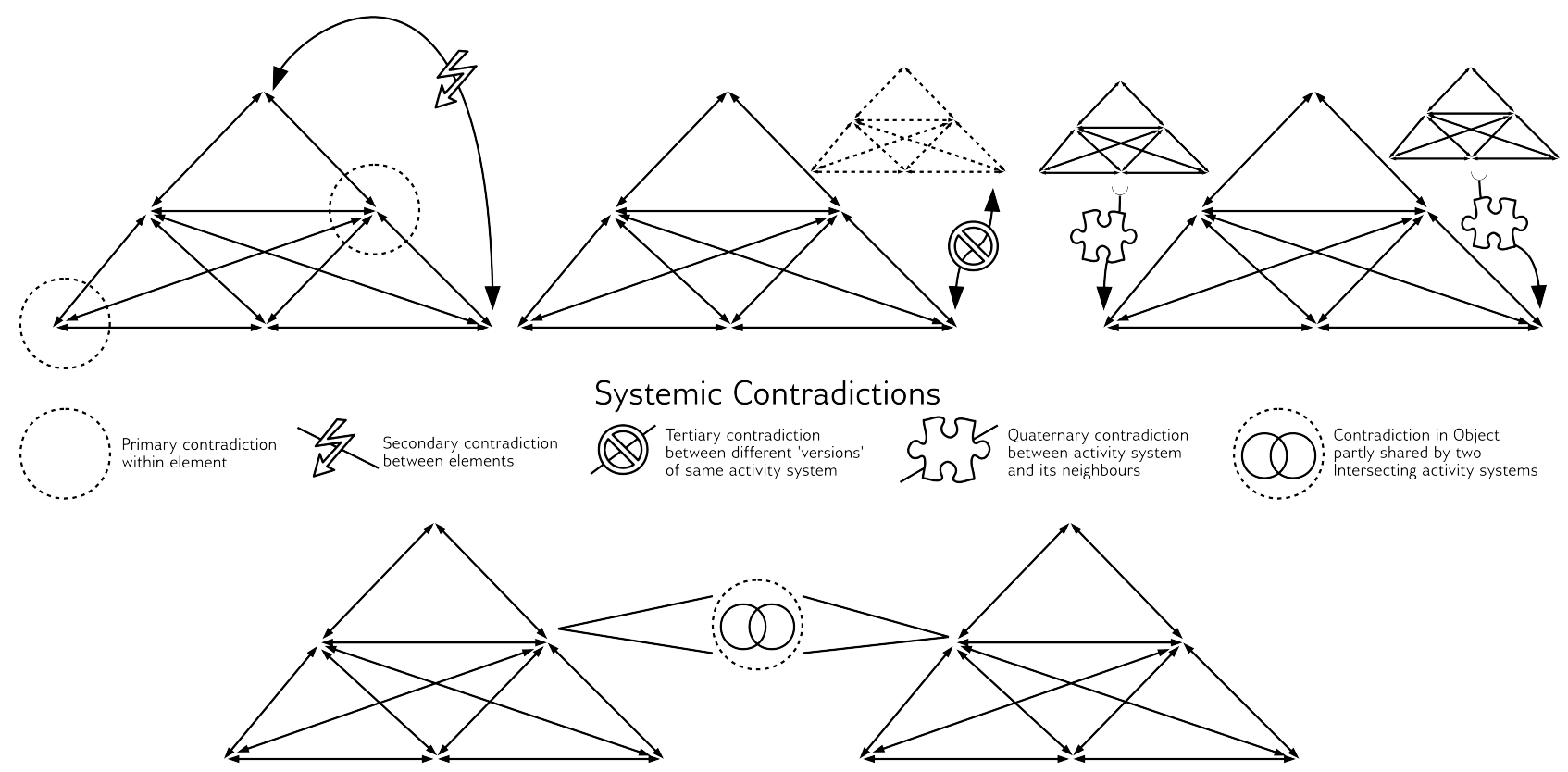

Figure 2: A graphical representation of systemic contradictions.

The numerical naming of contradictions is supposed to imply an order, based on assumptions of commodity relations pressures, i.e., capitalist market-forces. To consider an example: Virkkunen \& Newnham (2013) suggest that market changes might aggravate primary contradictions by altering exchange-value; subsequently, participants' initial change attempts might generate secondary contradictions because newly introduced elements are in contradiction with other elements of the system; addressing this situation involves producing a new object or artefacts for the activity system, but actual implementation still generates tertiary contractions as people attempt to use a new model while many established practices retain currency; furthermore, when the activity system is transformed, quaternary contradictions exist between the new system and those of its neighbours 
that functionally depend on the activity acting in the old way (pp. 52-53).

While "marketization" is one of the "grand issues" of higher education policy research (Tight, 2012, p. 118), it remains unsatisfactory to simply assume that some particular institutional change has been triggered by market-pressure. We argue that the distinction between forms of contradiction is useful in higher education, yet their order must simply be a matter for empirical investigation - for which the Change Laboratory would be a well-suited methodology.

Expansive learning involves people consciously re-imagining their activity; if they are successful, then the object of the activity is expanded (Engeström, 1987/2015, p. 134). Expansive learning requires more than reflection. Engeström (2008) suggests that it ought to be understood as the "construction and resolution of successively evolving tensions or contradictions in a complex system" (p. 131). Engeström's work suggests a cycle of expansive learning stages:

1. Questioning and criticising: people reject established wisdom, current practices, and existing plans;

2. Analysis: people investigate and represent the structure and history of the present situation;

3. Modelling: people pose a new, simplified model that aims to explain the situation in a public form and to suggest potential solutions;

4. Examination: people work with the model (in discussion or in practice) to better comprehend its dynamics, potential and limitations;

5. Implementation: people render the model more concrete by applying it practically and conceptually, so enriching and extending it;

6. Process reflection: people evaluate their current process, generating critique and identifying further requirements;

7. Consolidation and generalisation: people attempt to embed stable forms of new practice.

This cycle is considered an ideal-type; in practice, the cycle may proceed iteratively — containing sub-cycles — or particular cycles might be abandoned, with people returning to earlier phases. Subcycles might operate in parallel. In keeping with Marx's emphasis on "practical-critical" activity, the expansive learning cycle is used as a heuristic model for designing Change Laboratory interventions, and is itself subject to critique through analysis of successive interventions. As Engeström (2008) acknowledges:

one probably never finds a concrete collective learning process that cleanly follows the ideal-typical model [...] Every time one examines or facilitates a potentially expansive learning process with the help of the model, one tests, criticizes, and, hopefully, enriches the theoretical ideas of the model (p. 131).

The Change Laboratory is intended to comprise an intervention-research methodology closely coupled to expansive learning and activity theory, an attempt to facilitate expansive learning, an opportunity to enrich underlying theoretical perspectives by testing them in practice and-therefore -as an example of the practical-critical activity of ascending from the abstract to the concrete that underpins the dialectical materialist approach to knowledge production. 


\section{Methodology}

The Change Laboratory-itself a developing form of artefact-mediated activity (Virkkunen \& Newnham, 2013, pp. 217ff.) - involves attempting to intervene within another activity system so as to support expansive learning. Put simply, the Change Laboratory activity can be described thus:

A Change Laboratory is typically conducted in an activity system that is facing a major transformation. This is often a relatively independent pilot unit in a large organization. Working practitioners and managers of the unit, together with a small group of interventionist-researchers, conduct five to ten successive Change Laboratory sessions, often with follow-up sessions after some months. When feasible, also clients, customers or patients are invited to join Change Laboratory sessions in which their particular cases are analyzed in detail (Engeström, Rantavuori \& Kerosuo, 2013, p. 82).

Over the sequence of sessions, there is a gradually-shifting focus on particular expansive learning actions: questioning wisdom, analysing the extant situation, constructing models, examining those models, implementing pilots, reflecting on the process, and consolidating models. This description should not be interpreted mechanically. Sessions designed to focus on one particular expansive learning action often to do so in tandem with others (for example, examining a model will likely involve re-visiting modelling decisions).

Furthermore, participants deviate from the design-intentions of the researcher-interventionist. Such deviations are expected to gradually increase in frequency and are interpreted positively as an indication of participants' developing transformative agency. Ideally, participants trial ideas in their own practice, undertake local research that might feed into sessions_-such as investigating historical aspects of the institution, or asking colleagues or students for their views - and meet in sub-groups outside sessions to work intensively on particular issues.

Yet undertaking a Change Laboratory still involves careful attention to design, because the aim is to foster collective engagement with a definite process: expansive learning. The design of the sequence and the formulation of tasks within particular sessions both follow general principles.

\section{Designing a Change Laboratory sequence}

The overall aims of the research-intervention are broad: to reconceptualise the object of the institutional activity, to develop new artefacts, rules and divisions of labour, and potentially to reshape external relationships with other activities (Virkkunen \& Newnham, 2013, p. 9). The main prerequisite is that "practitioners can feel safe to freely express their opinions and are allowed to experiment with new ways of acting” (ibid., p. xix). Additionally, Virkkunen \& Newnham suggest negotiating a project outline with managers and workers and producing a briefing document; such negotiation usefully presages - publicly — the approach of the Change Laboratory. Here, we set out a range of the most pressing design issues:

- Setting out the theoretical underpinnings. Concepts like contradictions are unlikely to be familiar to participants. Furthermore, participants often perceive as counterintuitive the fact that developing solutions is not the opening focus. Providing a brief overview of the approach can help avoid confusion. 
- Identifying the intervention unit. The choice of intervention unit is consequential for concept implementation. Virkkunen \& Newnham (2013) assume some choice in the selection; they recommend an intervention unit where there is recognition of a need for change, an organisationally strategic position, and sufficient stability to cope if matters become intense (p. 65). Yet those undertaking higher education research may have little choice of selection. For example, those undertaking insider research might engage with their employing organisational unit (Trowler, 2014). This insider-Change Laboratory scenario seems poorly documented in the literature.

- Selecting participants. Change Laboratory sessions typically involve fewer than 20 people, for reasons of resource- and participation-management. Two important criteria for selecting participants are frequently in contradiction (Virkkunen \& Newnham, 2013, pp. 65-66). The first criterion is attention to group composition, since participants must speak openly and directly about practice problems and possibilities for change. The second criterion is that participants "are dealing with the same object in their daily work and are involved in realizing the same final outcome despite differences in their occupation, task or hierarchical position” (p. 65). So there is desire to capture an appropriate range of voices- to gain better insight and generate support for change-while trying to ameliorate the likelihood of local hierarchies stultifying contributions. Participant selection processes might be easier for insider-researchers due to greater familiarity with local dynamics.

- Scope and timing. Notwithstanding organisational pressures, there must be sufficient sessions to support consideration of the full range of expansive learning actions and necessary work in between sessions. Sessions need to take place sufficiently frequently that momentum is maintained for undertaking tasks or generating new evidence between sessions. Virkkunen \& Newnham (2013, p. 66) suggest that 5-12 sessions of around 2 hours' duration take place on a weekly basis.

- Identifying a venue. Undertaking sessions involves presenting audio-visual resources (possibly including video footage), drawing diagrams, supporting discussion and possibly recording aspects of what happens for future reflection. It is often assumed that formal sessions will occur consistently in a particular place. While this may not always be possible, considering requirements of room-size, furniture configuration, technology and the provision of multiple writing surfaces is essential when choosing a venue.

- Connecting the process to management. Practitioners must devote time to the intervention and will need managerial support to do so. Institutional change processes will also benefit from political support. Intensive discussion with management might be required at particular moments - for example, after the initial analysis phase, or when tools and actions need to be tested. Virkkunen and Newnham (2013) suggest forming a steering group to facilitate discussion with management. It is also suggested that minutes of Change Laboratory sessions are made publicly accessible outside the participating group.

- Generating mirror-data. Rendering practice problems and systemic contradictions obvious to participants within sessions will often involve presenting particular resources—called mirror-data. Mirror-data can take various forms, including documents, statistics and 
transcripts. Yet video footage and other image-heavy media are considered useful for provoking visceral reactions within sessions and conveying that problems exist undeniably.

Producing mirror-data will be a significant commitment for the researcher-interventionist throughout the intervention. Virkkunen \& Newnham (2013) suggest that researcher-interventionists might interview managers, practitioners and clients, observe work activity, and video-record Change Laboratory sessions. Participants might reflect on their work processes, the history of those processes, and their ongoing development (p. 70). Mirror-data should closely focus on concrete practice problems, new or exemplary client cases, and key routine actions (pp. 72-73). Mirror-data from various sources can be mutually complementary:

selected documents can be used to stimulate comments in an interview. The researcherinterventionist can show the practitioners their own video recorded action and ask them to comment on what they see in it and what they thought [when] carrying out the action. Asking the practitioners to explain the history, meaning, and way of using a frequently used form or other tool can open a window to the relationships between different functions of the activity (p. 74).

While research-ethics issues are not often discussed in the Change Laboratory literature, those working in higher education contexts will need to consider the ethical implications of gathering mirror-data when planning research-interventions.

\section{Designing particular tasks}

It is initially necessary to broadly map out tasks across the sequence: mapping sessions to expansive learning actions, determining attendance and resource requirements, and - a particular challengetrying to anticipate how later sessions might build on the processes and outcomes of earlier ones. Earlier sessions will be more rigidly planned by the researcher-interventionist yet, as the sequence moves on, the content of sessions becomes increasingly contingent on the earlier sessions and increasingly under the initiative of the participants themselves.

Tasks within Change Laboratory sessions are inspired by Vygotskyan dual-stimulation designs. Task-designs need to consider the following aspects:

- Mirror-data: materials used to represent practice-problems and contradictory situations to participants;

- First-stimulus: the task specification;

- Second-stimulus: the analytical tool or method to be used for addressing the first-stimulus task;

- Social organisation: the flow of participant work - considering moments of whole group, small group, or individual working;

- Documentation: how individuals or sub-groups externalise their thinking for discussion with others;

- Discussion and recording: how people come together to discuss tasks and debate solutions, and how those discussions are recorded in ways that can be re-used later. 
Task-designs in sessions should focus on particular expansive learning actions. Commonly, documents, recordings or models produced in particular sessions are re-used as mirror-data or second-stimulus material within subsequent tasks. Furthermore, analysis of earlier sessions will influence to some degree the first-stimulus tasks designed for subsequent sessions.

Some examples taken from guidance in the literature are summarised in Table 1. The formulation of tasks focussed on analysis is particularly closely specified within the Change Laboratory literature. Expansive learning actions have a range of sub-types that can occur in Change Laboratory projects (Engeström, Rantavuori \& Kerosuo, 2013, p. 93). Yet the action of analysis is unusual in having two sub-types that must be explicitly designed for (Virkkunen and Newnham, 2013). Historical analysis involves mapping how the current activity has developed over time, while actualempirical analysis aims to more explicitly locate identified problems in their wider systemic context. Due to the importance of both of these sub-types, they are considered separately in the table.

Table 1: Summary of task examples devoted to different expansive learning actions. Second-stimuli diagrams can be found in Engeström (2008).

\begin{tabular}{|c|c|c|c|c|}
\hline $\begin{array}{c}\text { Expansive } \\
\text { learning action }\end{array}$ & Mirror-data & First-stimuli & Second-stimuli & $\begin{array}{c}\text { Comments for researcher- } \\
\text { interventionists }\end{array}$ \\
\hline Questioning & $\begin{array}{l}\text { Autobiographical } \\
\text { accounts of practice } \\
\text { (perhaps provided by } \\
\text { practitioners) }\end{array}$ & $\begin{array}{l}\text { Identify the practice-problems } \\
\text { that are being described } \\
\text { Identify elements of activity that } \\
\text { contribute to the problem }\end{array}$ & $\begin{array}{l}\text { Concepts such as } \\
\text { disturbance or } \\
\text { rupture }\end{array}$ & $\begin{array}{l}\text { Encourage participants to talk } \\
\text { about aspects of their work they are } \\
\text { passionate about. } \\
\text { Ensure movement between } \\
\text { moments of emotional energy and } \\
\text { detached analysis. }\end{array}$ \\
\hline $\begin{array}{l}\text { Analysis: } \\
\text { historical }\end{array}$ & $\begin{array}{l}\text { Timelines from } \\
\text { institutional } \\
\text { documents, from } \\
\text { interviews, or } \\
\text { developed in-session }\end{array}$ & $\begin{array}{l}\text { Map how the object of activity } \\
\text { has changed over time; identify } \\
\text { which other activity system } \\
\text { elements have changed and when }\end{array}$ & $\begin{array}{l}\text { Activity system } \\
\text { model }\end{array}$ & $\begin{array}{l}\text { Encourage investigation of how } \\
\text { earlier contradictions underpinned } \\
\text { the development of the current } \\
\text { activity system }\end{array}$ \\
\hline $\begin{array}{l}\text { Analysis: actual- } \\
\text { empirical }\end{array}$ & $\begin{array}{l}\text { Video-recordings of } \\
\text { workplace encounters } \\
\text { or interviews } \\
\text { Activity system } \\
\text { representations } \\
\text { developed earlier }\end{array}$ & $\begin{array}{l}\text { Identify intention-outcome } \\
\text { differences } \\
\text { Identify forms of collaboration } \\
\text { used } \\
\text { Map activity system development } \\
\text { as a historical work-type }\end{array}$ & $\begin{array}{l}\text { Concepts such as } \\
\text { disturbance or } \\
\text { rupture }\end{array}$ & $\begin{array}{l}\text { Develop hypotheses about systemic } \\
\text { contradictions. } \\
\text { Support further development of } \\
\text { existing activity system } \\
\text { representations }\end{array}$ \\
\hline Modelling & $\begin{array}{l}\text { Activity system } \\
\text { representations } \\
\text { developed earlier } \\
\text { Video-recordings of } \\
\text { practice and } \\
\text { interviews }\end{array}$ & $\begin{array}{l}\text { Identify people who might } \\
\text { become involved in the activity } \\
\text { in future; effects of policy } \\
\text { change; change already } \\
\text { happening } \\
\text { Identify what is desirable and } \\
\text { undesirable about alternate } \\
\text { models }\end{array}$ & $\begin{array}{l}\text { Activity system } \\
\text { model labelled with } \\
\text { forms of } \\
\text { contradictions } \\
\\
\text { Activity system } \\
\text { model considering } \\
\text { neighbours concept }\end{array}$ & 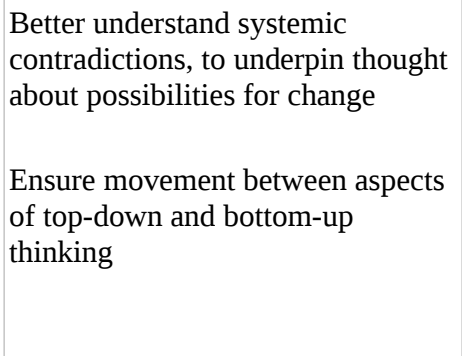 \\
\hline
\end{tabular}




\begin{tabular}{|c|c|c|c|c|}
\hline & $\begin{array}{l}\text { Models and } \\
\text { documents from other } \\
\text { institutions }\end{array}$ & $\begin{array}{l}\text { Sketch a new activity system idea } \\
\text { and then work through actions } \\
\text { and elements (top-down thinking) } \\
\text { Identify desirable components } \\
\text { (elements, actions) of a new } \\
\text { activity system and imagine the } \\
\text { surrounding activity model } \\
\text { (bottom-up thinking) }\end{array}$ & & \\
\hline Examination & $\begin{array}{l}\text { Videos and } \\
\text { documents } \\
\text { representing test-case } \\
\text { situations }\end{array}$ & $\begin{array}{l}\text { Work through how the new and } \\
\text { existing models would differ in } \\
\text { each of the test cases } \\
\text { Imagine using aspects of the new } \\
\text { models in practice between } \\
\text { sessions }\end{array}$ & $\begin{array}{l}\text { Models developed } \\
\text { by participants } \\
\text { Table of actions } \\
\text { and elements with } \\
\text { columns for each } \\
\text { activity system }\end{array}$ & $\begin{array}{l}\text { Sub-groups of participants might } \\
\text { test new models developed by } \\
\text { others }\end{array}$ \\
\hline Implementation & $\begin{array}{l}\text { Everyday practice } \\
\text { (outside sessions) }\end{array}$ & $\begin{array}{l}\text { Implement aspects of the new } \\
\text { models 'experimentally'; note } \\
\text { consequences, problems and } \\
\text { opportunities for further } \\
\text { development } \\
\text { Gauge reactions from colleagues } \\
\text { Alert researcher-interventionist to } \\
\text { possibilities to record mirror-data }\end{array}$ & $\begin{array}{l}\text { Models developed } \\
\text { by participants }\end{array}$ & $\begin{array}{l}\text { Participants taking ownership and } \\
\text { responsibility is crucial }\end{array}$ \\
\hline $\begin{array}{l}\text { Process } \\
\text { reflection }\end{array}$ & 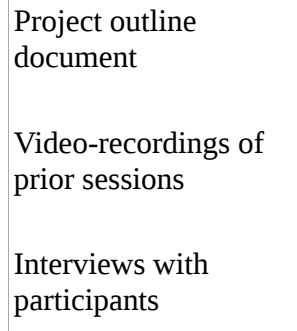 & $\begin{array}{l}\text { Identify factors supporting or } \\
\text { restricting expansive learning } \\
\text { Identify how participants have } \\
\text { changed their thinking about the } \\
\text { new work activity }\end{array}$ & $\begin{array}{l}\text { Cycle of expansive } \\
\text { transformation } \\
\text { Models developed } \\
\text { by participants }\end{array}$ & 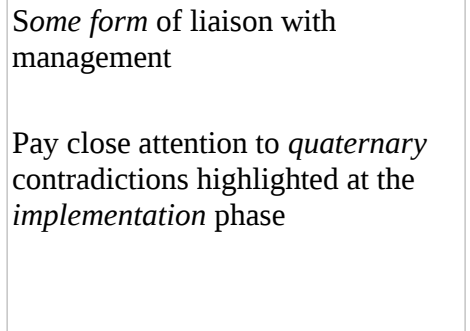 \\
\hline Consolidation & $\begin{array}{l}\text { Institutional } \\
\text { documentation } \\
\text { examples }\end{array}$ & $\begin{array}{l}\text { Clarify those concepts and } \\
\text { models as organisational } \\
\text { principles and new vocabulary } \\
\text { Produce a "road map" of } \\
\text { subsequent changes } \\
\text { Arrange subsequent action }\end{array}$ & $\begin{array}{l}\text { Models developed } \\
\text { by participants }\end{array}$ & $\begin{array}{l}\text { Management coordination } \\
\text { important } \\
\text { Consider what happens when the } \\
\text { researcher-interventionist moves on } \\
\text { and/or funding ceases } \\
\text { Produce written output } \\
\text { documentation }\end{array}$ \\
\hline
\end{tabular}

\section{Application}

We now focus on five example projects in higher education settings. Those projects are diverse, focussing on scholarly communication, library services, service-agreements between institutions, pre-service teacher education and integrating technology into teaching. An overview is provided in Table 2. Our account is based on the published outputs from those projects; inevitably, these offer varying levels of detail. It seems consequential that Change Laboratory interventions generate voluminous data. Projects may be reported across multiple publications that emphasise different 
aspects of the outcomes (e.g., Ellis 2008, 2010, 2011). It seems difficult to comprehensively map intention, design and outcomes within particular publications, which serves to obscure those links from critical analysis. Nonetheless, it seems evident that the five projects we examine here did adhere to the core Change Laboratory principles of expansive learning and dual-stimulation taskdesign. For present purposes, we are concerned with the adoption, application and outcomes of the methodology for the five research-interventions.

\section{Adoption and use}

In all five cases, the stated reasons for choosing the Change Laboratory included its participatory nature and focus on systemic development rather than individual performance. Particular advantages over other "participatory" approaches were also suggested. For example, Ellis (2008) argues that the approach enables practitioners but "doesn't sentimentalise them and requires a realistic, cultural-historical understanding of both social structures and practices" (p. 54). Furthermore, Glover \& Miller (2009) argue, counterintuitively, that the directionality of the Change Laboratory presents advantages_-including a "potential for greater creativity" (p. 473) and a way of avoiding more powerful participants dominating the agenda.

The Change Laboratory offers specific methodological guidance but flexibility in implementation and this is reflected in the five projects. One heterodox research-intervention was that reported by Ellis (2011). That intervention scheduled sessions over a timescale of 2 years, was coordinated by an insider researcher-interventionist, and was constrained to exclude the use of video-footage as mirror-data. Ellis (2008) describes the approach as "DWR-lite" (p. 54), yet the intervention retains a focus on dual-stimulation tasks corresponding to expansive learning actions. The intervention reported by Glover \& Miller (2009) incorporates a slightly amended, previously published version of the expansive learning cycle, based around six rather than seven learning actions. Others gathered mirror-data using atypical methods; for example, St. Clair Browne (2011) specifically incorporated focus groups into his sequence design.

Regrettably, specific descriptions of dual-stimulation task-designs were largely absent from the literature examined. Glover and Miller (2009) do refer to some general features of their sessions, rather than tasks. Their sessions followed a particular, conventional sequence-reflection, sharing news, using previously developed materials, and developing new resources.

\section{Contradictions and outcomes}

In some cases, contradictions are well-documented. Within the project focussed on pre-service teacher education (Ellis, 2008), primary contradictions were identified within the object of activity, between poles of teacher-identity and teacher-agency. Attendant secondary contradictions highlighted that students on placement were simultaneously potential recruits, resource-burdens for schools, and free supply cover. Arising from this analysis, participants developed an alternative concept of teacher-agency that subsequently underpinned new practices. In other cases, contradictions are documented only implicitly. For example, in the intervention focussed on technology integration (Glover \& Miller, 2009), contradictions are implied between traditions of using interactive whiteboards as presentation tools and their more interactive capabilities. The 
development of resource materials subsequently focussed on this issue, but the attendant paper does not explicitly report the links between the contradictions and the design of artefacts.

Reported outcomes of interventions frequently diverge from their original, stated aims; this divergence is valued, though its extent varies. Engeström, Rantavuori \& Kerosuo (2013) distinguish between divergence at the action-level, where participants merely diverge from task intentions, and at the object-level, where deviation is consolidated and transforms the original object of the research-intervention. Both situations were found in their university library intervention, with action-level deviations retrospectively recognised as precursors to one, major object-level deviation. Engeström, Rantavuori \& Kerosuo (2013) suggest that after their project's rather "contained, sterile" early sessions, the object-level deviation "led to a burst of modeling and examining actions that intensified and energized the process, as if the agency of the practitioners were finally starting to break out of the confines of traditional top-down development" (p. 102).

Table 2: Summary overview of five Change Laboratory research-interventions in higher education.

\begin{tabular}{|c|c|c|c|c|}
\hline Project, Publications & $\begin{array}{l}\text { Participants, } \\
\text { Institution }\end{array}$ & Project focus & $\begin{array}{l}\text { Description of Change } \\
\text { Laboratory Sessions }\end{array}$ & $\begin{array}{c}\text { Examples of mirror-data } \\
\text { used }\end{array}$ \\
\hline $\begin{array}{l}\text { Scholarly } \\
\text { Communication at } \\
\text { the University of } \\
\text { Botswana } \\
\text { (Trotter et al., 2014) }\end{array}$ & $\begin{array}{l}\text { University managers } \\
\text { and librarians, } \\
\text { varying from 7-13 } \\
\text { participants per } \\
\text { session } \\
\text { University of } \\
\text { Botswana }\end{array}$ & $\begin{array}{l}\text { Research } \\
\text { communication: practice, } \\
\text { values, impact, cost- } \\
\text { benefit } \\
\\
\text { Part of a wider initiative } \\
\text { across four African } \\
\text { countries }\end{array}$ & $\begin{array}{l}\text { Four day-long sessions } \\
\text { Identifying activity system } \\
\text { elements; identifying } \\
\text { contradictions; producing } \\
\text { "concept notes"; reflection } \\
\text { (pp. 26-27) }\end{array}$ & Not described \\
\hline $\begin{array}{l}\text { Knotworking in the } \\
\text { Library } \\
\text { (Engeström et al., } \\
\text { 2012; Engeström, } \\
\text { Rantavuori \& } \\
\text { Kerosuo, 2013) }\end{array}$ & $\begin{array}{l}\text { Library staff, } \\
\text { academics } \\
\text { representing research } \\
\text { groups }\end{array}$ & $\begin{array}{l}\text { Creating a new model of } \\
\text { library services for } \\
\text { researchers and research } \\
\text { groups against the } \\
\text { background of the } \\
\text { emerging crisis of } \\
\text { university libraries } \\
\text { worldwide. } \\
\text { Researcher-librarian } \\
\text { partnership for data } \\
\text { management. }\end{array}$ & 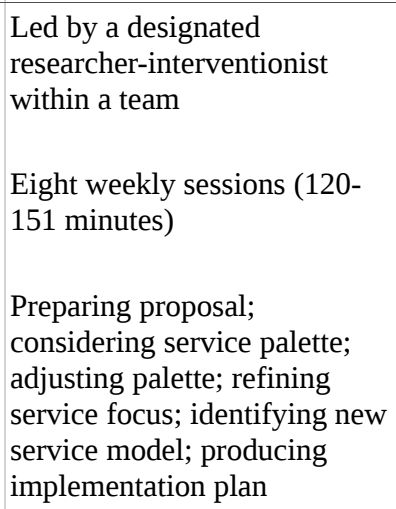 & $\begin{array}{l}\text { Employee and client video- } \\
\text { interviews on problems and } \\
\text { needs relating to the library }\end{array}$ \\
\hline $\begin{array}{l}\text { Implementation of } \\
\text { shared services across } \\
\text { three tertiary } \\
\text { institutions } \\
\text { St. Clair Browne } \\
\text { (2011) }\end{array}$ & $\begin{array}{l}\text { Academics } \\
\text { (Education, } \\
\text { Psychology), } \\
\text { professional members } \\
\text { of the Higher } \\
\text { Education } \\
\text { Development Unit } \\
\\
\text { Three tertiary- } \\
\text { education } \\
\text { institutions, Barbados }\end{array}$ & $\begin{array}{l}\text { Work practices of the } \\
\text { project-planning group } \\
\text { developing shared } \\
\text { services. }\end{array}$ & $\begin{array}{l}\text { Facilitated by single } \\
\text { researcher-interventionist } \\
\text { Three sessions of } 1 \text { hour } 30 \\
\text { minutes duration } \\
\text { Identifying systemic } \\
\text { contradictions; refining } \\
\text { object; changes in practice } \\
\text { (pp. 79-81) }\end{array}$ & $\begin{array}{l}\text { Interview transcripts } \\
\text { Focus group transcripts }\end{array}$ \\
\hline $\begin{array}{l}\text { Developing English } \\
\text { Teaching and }\end{array}$ & $\begin{array}{l}\text { Mentors of pre- } \\
\text { service teacher }\end{array}$ & $\begin{array}{l}\text { To reconfigure a school- } \\
\text { university partnership; to } \\
\text { develop "collaborative }\end{array}$ & $\begin{array}{l}\text { Facilitated by one researcher- } \\
\text { interventionist with a research } \\
\text { assistant }\end{array}$ & $\begin{array}{l}\text { Interview transcripts (e.g., } \\
\text { with school headteachers) }\end{array}$ \\
\hline
\end{tabular}




\begin{tabular}{|c|c|c|c|c|}
\hline $\begin{array}{l}\text { Internship Learning } \\
\text { Design of a teacher- } \\
\text { education programme } \\
\text { Ellis }(2008,2011)\end{array}$ & $\begin{array}{l}\text { education } \\
\text { University of Oxford }\end{array}$ & $\begin{array}{l}\text { professional inquiry" as a } \\
\text { systemic tool in } \\
\text { professional learning } \\
\text { (2008). } \\
\text { To break with the } \\
\text { existing design for a } \\
\text { teacher-education } \\
\text { programme by } \\
\text { introducing new ideas } \\
\text { and ways of working } \\
\text { (2011). }\end{array}$ & $\begin{array}{l}\text { Held every } 2 \text { months for } 2 \\
\text { years }\end{array}$ & $\begin{array}{l}\text { Emails } \\
\text { Photographs and images } \\
\text { Transcripts of observations }\end{array}$ \\
\hline $\begin{array}{l}\text { Professional } \\
\text { development of } \\
\text { teachers and } \\
\text { university staff in } \\
\text { optimising the use of } \\
\text { interactive } \\
\text { whiteboard } \\
\text { technology } \\
\text { Glover \& Miller } \\
\text { (2009) }\end{array}$ & $\begin{array}{l}\text { University } \\
\text { mathematics } \\
\text { lecturers, secondary } \\
\text { mathematics } \\
\text { teachers, institutional } \\
\text { managers, advanced- } \\
\text { skills teachers } \\
\text { Keele University }\end{array}$ & 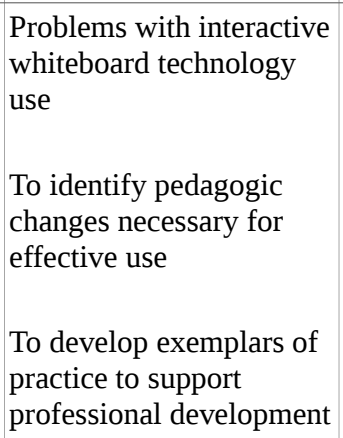 & 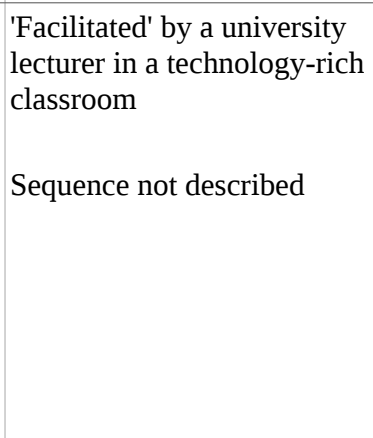 & $\begin{array}{l}\text { Mathematician-generated } \\
\text { examples of good practice }\end{array}$ \\
\hline
\end{tabular}

\section{An example of a task design}

Task-design is perfunctorily described in these higher education examples, despite being central to the Change Laboratory approach. To illustrate the issue, we present an example from a researchintervention of our own, focussed on whole-curriculum redesign in Pharmacy education. The project was initially necessitated by new, external regulatory-accreditation requirements for curriculum integration across a five-year programme. Local practitioners wished to incorporate pedagogically-integrated models (e.g., Harden, 2000) and examine international comparators (e.g., Husband et al., 2014).

The task described in Table 3 constitutes actual-empirical analysis of existing work practices; it was used in an early session undertaken four times with parallel disciplinary groups. Groups developed an activity system model of their discipline's input into the existing curriculum. The resulting models were later used as second-stimulus_-participants were asked to identify elements that did not fit their evolving conceptualisations of an integrated curriculum, how those elements might differ in future, and the likely impact on existing institutional practices. That work identified secondary contradictions in the activity system and developed an understanding that considerable change would be needed in the socially-mediated distribution and exchange processes.

Table 3: Example task-design from a Change Laboratory project about curriculum re-design in Pharmacy education

\begin{tabular}{|l|l|}
\hline Mirror-data & Existing curriculum document, displayed across room wall in four sections. \\
& Live access to Virtual Learning Environment. \\
& Recent graduate to answer queries about the student experience ("live mirror"). \\
\hline
\end{tabular}




\begin{tabular}{|c|l|}
\hline First-stimulus & How does your unit currently provide teaching-related services to pharmacy undergraduate students? \\
\hline Second-stimulus & 'Blank' activity system representation on flipcharts, documents outlining meanings of terms. \\
\hline $\begin{array}{c}\text { Social } \\
\text { organisation }\end{array}$ & $\begin{array}{l}\text { Whole-group: semi-circular seating arrangement so participants could see the flipchart and researcher- } \\
\text { interventionist while also facing other participants. }\end{array}$ \\
\hline Documentation & $\begin{array}{l}\text { Participants had their own pre-printed "lab book" in which to write particular information. The workbook } \\
\text { design matched the planned flow of the sessions, so that participants could refer to definitions and tasks and } \\
\text { make notes while other participants were speaking. }\end{array}$ \\
\hline $\begin{array}{c}\text { Discussion and } \\
\text { recording }\end{array}$ & $\begin{array}{l}\text { The Lab Book acted as a personalised record of whole-group and small-group discussions. Participants were } \\
\text { asked to write on the flipcharts directly, or affixing post-it notes, to ensure that where possible all views could } \\
\text { be displayed publicly, everyone's opinion was considered and progress was consolidated. Whole group } \\
\text { discussion was audio-recorded; where small-group discussions took place, sub-groups were asked to feed back } \\
\text { to the wider group and those summaries were audio-recorded. }\end{array}$ \\
\hline
\end{tabular}

\section{Discussion and Conclusion}

Compared with many methodologies used in higher education research, the Change Laboratory is particularly closely-coupled to its theoretical underpinnings. The vantage point that human consciousness develops within activity under particular objective conditions arises directly from dialectical-materialist thought; as does the priority accorded to conceptual development, systemic analysis, and the comprehension of practice through change. The focus on artefact-mediation, double-stimulation tasks, object-oriented activity, activity systems, and contradictions, on the other hand, stems from how the methodology directly attempts to apply activity theory research principles to real-world interventions - in ways that rely on participants themselves comprehending and directly using many of those research principles. The Change Laboratory can boast exceptionally close alignment between ontology, epistemology, theory and methodology, but this comes with a cost, viz., that researcher-interventionists and participants are expected to use unfamiliar concepts and counterintuitive intervention procedures.

Is this a cost worth bearing? Provisionally: yes. Despite their initial bewilderment about "Viv's triangle thing" (Viv Ellis, 2008, pp. 56-57), participants in the teacher-education project made impressive conceptual developments. Trotter et al. (2014) patiently explained contradictions as "misalignments"; yet a formidable list of contradictions was identified. All five higher education projects suggest successful outcomes that mirror those in the wider Change Laboratory literature: organisations were changed, concepts developed, and participants empowered.

Yet there are contradictions in the practices as documented. We shall note some evident examples. A primary contradiction exists in the object of the activity: is the Change Laboratory interventionresearch or research-intervention? In other words, which aspect is to be prioritised when the valuesystems of research and intervention diverge? A secondary contradiction might be called culturallocalism. This contradiction exists between the rules of the activity — which set such high value on local-historical development that Engeström, Rantavuori \& Kerosuo (2013, p. 84 n. 2) consider prior studies of library development of limited relevance to their project—and the division of 
labour, which tasks people to investigate culturally more advanced activity systems as models. Precisely where the boundary lies between the "culturally more advanced" and the "non-local" requires clarification and careful consideration of the concepts culture and locality. One tertiary contradiction that exists between new and existing forms of practical-critical activity is not unique to higher education settings, but may take uncommon forms; many local practitioners will have explicit pre-existing ontological and epistemological stances, and theoretical commitments on issues ranging from teaching-and-learning to organisational change. Such worked-through positions will have a different resonance within the research-intervention than typical practitioner resistance or common-sense. Finally, as already discussed, one evident quaternary contradiction between the Change Laboratory and neighbouring local activities relates to line-management, an issue likely to be exacerbated by common insider-research scenarios in higher education research.

As people confront these contradictions - and others-they will develop the Change Laboratory. At present, there exist no specialised variants of the Change Laboratory for higher education, as have been developed in healthcare and elsewhere, and these may need to be forthcoming. Much theorising in the higher education research field already draws on activity theory, and connecting to those more specialised, instantiated models introduces the possibility of enriching the methodology and more authentically developing the models themselves, many of which have hitherto been used merely as heuristic devices for categorising data. In this way, both higher education research and the Change Laboratory will necessarily ascend from the abstract to the concrete.

\section{References}

Blunden, A. (2010). An Interdisciplinary Theory of Activity. Leiden: Brill.

Darwin, S. (2011). Learning in activity: exploring the methodological potential of action research in activity theorising of social practice. Educational Action Research, 19(2), 215-229.

Ellis, V. (2008). Exploring the contradictions in learning to teach: the potential of Developmental Work Research. Changing English, 15(1), 53-63.

Ellis, V. (2010). Impoverishing experience: the problem of teacher education in England. Journal of Education for Teaching, 36(1), 105-120.

Ellis, V. (2011). Reenergising professional creativity from a CHAT perspective: Seeing knowledge and history in practice. Mind, Culture, and Activity, 18(2), 181-193.

Engeström, Y. (2015). Learning by Expanding: An activity-theoretical approach to developmental research. Second edition. New York: Cambridge University Press.

Engeström, Y., Rantavuori, J., \& Kerosuo, H. (2013). Expansive learning in a library: Actions, cycles and deviations from instructional intentions. Vocations and Learning, 6(1), 81-106.

Engeström, Y., Sannino, A., \& Virkkunen, J. (2014). On the methodological demands of formative interventions. Mind, Culture, and Activity, 21(2), 118-128.

Engeström, Y., Kaatrakoski, H., Kaiponen, P., Lahikainen, J., Laitinen, A., Myllys, H., Rantavuori, 
J. \& Sinikara, K. (2012). Knotworking in academic libraries: Two case studies from the University of Helsinki. Liber Quarterly, 21(3/4), 387-405.

Engeström, Y. (2008). From Teams to Knots: Activity-theoretical studies of collaboration and learning at work. Cambridge: Cambridge University Press.

Fullan, M. (1999). Change Forces: The Sequel. London: RoutledgeFalmer.

Glover, D. \& Miller, D. (2009). Optimising the use of interactive whiteboards: an application of developmental work research (DWR) in the United Kingdom. Professional Development in Education, 35(3), 469-483.

Harden, R.M. (2000). The integration ladder: a tool for curriculum planning and evaluation. Medical Education, 34(7), 551-557.

Husband, A.K., Todd, A., \& Fulton, J. (2014). Integrating science and practice in Pharmacy curricula. American Journal Of Pharmaceutical Education, 78(3), article 63.

Horn, A.J. (2013). The Enigma of the Inversion: Part Two: 'Turned Right Side Up Again'. Critique 41(3), 339-369.

Kaptelinin, V. \& Nardi, B.A. (2006). Acting with Technology: Activity theory and interaction design. Cambridge, MA: MIT Press.

Lewin, K. (1947). Frontiers in Group Dynamics: Concept, method and reality in social science; social equilibria and social change. Human Relations, 1(1), 5-41.

Marx, K. (1976). Theses on Feuerbach. Karl Marx, Frederick Engels: Collected Works. Volume 5. Marx and Engels 1845-1847 (pp. 3-9). London: Lawrence \& Wishart.

Marx, K. (1979). The Eighteenth Brumaire of Louis Bonaparte. Karl Marx, Frederick Engels: Collected Works. Volume 11. Marx and Engels 1851-1853 (pp. 99-197). London: Lawrence \& Wishart.

Ollman, B. (2003). Dance of the Dialectic: Steps in Marx's method. Urbana: University of Illinois Press.

Penuel, W. (2014). Emerging forms of formative intervention research in education. Mind, Culture, and Activity, 21(2), 97-117.

Sannino, A. (2011). Activity theory as an activist and interventionist theory. Theory \& Psychology, 21(5), 571-597.

St. Clair Browne, C. (2011). Working Towards Institutional Change. PhD thesis. Bath: Department of Education, University of Bath.

Tight, M. (2012). Researching Higher Education. Second edition. Maidenhead: Open University Press.

Trotter, H., Kell, C., Willmers, M., Gray, E., Totolo, A., \& King, T. (2014). Scholarly communication at the University of Botswana: Case study report. Ottawa: IDRC. 
Trowler, P. (2014). Doing Insider Research in Universities. North Charleston: CreateSpace. Virkkunen, J. \& Newnham, D.S. (2013). The Change Laboratory: A tool for collaborative development of work and education. Rotterdam: Sense Publishers.

Wertsch, J.V. (2007). Mediation. In H. Daniels, M. Cole \& J.V. Wertsch (Eds.) The Cambridge Companion to Vygotsky (pp. 178-192). Cambridge: Cambridge University Press.

Williams, R. (1983). Keywords: A vocabulary of culture and society. Second edition. London: Flamingo.

Bligh, B. \& Flood, M. (in press). The Change Laboratory in Higher Education: researchintervention using activity theory. To appear in: J. Huisman \& M. Tight (Eds.) Theory and Method in Higher Education Research III. Bingley: Emerald. 